\title{
Hyperosmolar non-ketotic diabetic syndrome precipitated by treatment with diuretics
}

\author{
VIVIAN FONSECA, DAVID N PHEAR
}

The hyperosmolar non-ketotic diabetic syndrome, first reported in $1957,{ }^{1}$ is being diagnosed with greater frequency. ${ }^{2}$ Several cases have been reported of this syndrome being precipitated by treatment with diuretics, especially thiazide diuretics and frusemide. ${ }^{3-9}$ Diuretic treatment lasted from 15 days $^{4}$ to 4 years $^{8}$ before the syndrome developed. We reviewed the case notes of a consecutive series of 11 patients with the hyperosmolar non-ketotic diabetic syndrome to find out how often diuretic treatment precipitated it. The criteria used for diagnosis were severe hyperglycaemia (blood glucose greater than $30 \mathrm{mmol} / \mathrm{l}$ $(541 \mathrm{mg} / 100 \mathrm{ml})$ ), absence of ketoacidosis, dehydration, variable neurological signs, including depressed sensorium or frank coma, and serum osmolarity above $340 \mathrm{mOsm} / \mathrm{kg}$ (calculated using the formula: osmolarity (mOsm $/ \mathrm{kg}) 2 \times$ (serum sodium + potassium) + blood glucose + blood urea).

\section{Case report}

One week before admission a woman aged 59 years was started on treatment for symptomless hypertension with Moduretic (amiloride $5 \mathrm{mg}$ and hydrochlorothiazide $50 \mathrm{mg}$ ) two tablets daily. There was no family history of diabetes and no glycosuria. Soon after starting treatment she became tired, weak, thirsty, and had polyuria. On admission she was afebrile, drowsy,

Queen Elizabeth II Hospital, Welwyn Garden City, Herts AL7 4HQ VIVIAN FONSECA, MD, MRCP, medical registrar

DAVID N PHEAR, MD, FRCP, consultant physician
Diuretics may precipitate hyperosmolar nonketotic diabetes, particularly in elderly people

confused, and severely dehydrated but not acidotic. Investigations showed haemoglobin $17.6 \mathrm{~g} / \mathrm{dl}$, packed cell volume 0.54 $(54 \%)$, serum Na $156 \mathrm{mmol}(\mathrm{mEq}) / \mathrm{l}$, serum K $5.9 \mathrm{mmol}(\mathrm{mEq}) / 1$, bicarbonate $24 \mathrm{mmol}(\mathrm{mEq}) / \mathrm{l}$, blood urea $50 \mathrm{mmol} / \mathrm{l}(301 \mathrm{mg} / 100$ $\mathrm{ml}$ ), blood glucose $31.6 \mathrm{mmol} / 1(569 \mathrm{mg} / 100 \mathrm{ml})$, and serum osmolarity $405 \mathrm{mOsm} / \mathrm{kg}$. She was carefully rehydrated and the diabetes brought under control with small doses of insulin. She was also given prophylactic heparin. She recovered rapidly, the diabetes being controlled later by reducing diet, and the hypertension by atenolol $100 \mathrm{mg}$ daily.

Details of 11 patients admitted with the hyperosmolar nonketotic diabetic syndrome are summarised in the table. Two patients died, one from a myocardial infarction. Of the survivors, four required insulin for control of diabetes and two were controlled on diet alone, the rest being controlled with oral hypoglycaemics in modest dosage. Two of the four patients needing insulin did not develop the syndrome while on diuretics (cases 2 and 3). None of the patients were given diuretics after recovery and hyperosmolar non-ketotic diabetes did not recur. (Eight patients were followed up for at least a year.)

\section{Discussion}

The hyperosmolar non-ketotic diabetic syndrome has been called "an iatrogenic disease of increasing incidence." 3 Thiazides

Details of 11 patients who developed hyperosmolar non-ketotic diabetes after diuretic treatment

\begin{tabular}{|c|c|c|c|c|c|c|c|c|c|c|c|}
\hline $\begin{array}{l}\text { Case } \\
\text { No }\end{array}$ & $\begin{array}{l}\text { Previous } \\
\text { diabetes }\end{array}$ & $\begin{array}{c}\text { Age } \\
\text { (years)/ } \\
\text { sex }\end{array}$ & Drugs & $\begin{array}{c}\text { Duration of } \\
\text { treatment }\end{array}$ & $\begin{array}{c}\text { Blood } \\
\text { glucose } \\
(\mathrm{mmol} / \mathrm{l})\end{array}$ & $\underset{(\mathrm{mmol} / 1)}{\mathrm{Na}}$ & $\underset{(\mathrm{mmol} / \mathrm{l})}{\mathrm{K}}$ & $\begin{array}{c}\text { Blood } \\
\text { urea } \\
(\mathrm{mmol} / \mathrm{l})\end{array}$ & $\underset{(\mathrm{mmol} / \mathrm{l})}{\mathrm{HCO}_{\mathrm{s}}}$ & Osmolarity & Outcome \\
\hline 1 & No & $60 / \mathrm{F}$ & $\begin{array}{l}\text { Moduretic } 2 \text { tablets } \\
\text { daily }\end{array}$ & $3 \mathrm{wk}$ & $3 \cdot 2$ & 156 & 6 & 50 & 24 & 406 & $\begin{array}{l}\text { Recovered; diabetes } \\
\text { controlled on diet }\end{array}$ \\
\hline 2 & No & $71 / \mathrm{F}$ & - & - & 75 & 136 & 5 & 43 & 24 & 400 & $\begin{array}{l}\text { Recovered; diabetes } \\
\text { controlled on insulin }\end{array}$ \\
\hline 3 & No & $64 / M$ & - & - & 39 & 156 & 4 & 22 & 27 & 381 & $\begin{array}{l}\text { Recovered; diabetes } \\
\text { controlled on insulin }\end{array}$ \\
\hline 4 & No & $75 \mathrm{~F}$ & Indapamide $2.5 \mathrm{mg}$ & $3 \mathrm{mnth}$ & 42 & 147 & $4 \cdot 3$ & 24 & 22 & 369 & $\begin{array}{l}\text { Recovered; diabetes } \\
\text { controlled by diet }\end{array}$ \\
\hline 5 & No & $68 / M$ & $\begin{array}{l}\text { Propranolol } 80 \mathrm{mg} \text { qds; } \\
\text { bumetanide }\end{array}$ & $1 \mathrm{y}$ & 115 & 143 & 5 & 17 & 22 & 428 & $\begin{array}{l}\text { Recovered; controlled on } \\
\text { insulin and propranolol }\end{array}$ \\
\hline 6 & No & $79 \mathrm{~F}$ & $\begin{array}{l}\text { Cyclopenthiazide } 0 \cdot 5 ; \\
\text { oxprenolol } 80 \mathrm{mg}\end{array}$ & $2 \mathrm{mnth}$ & 34 & 144 & $4 \cdot 5$ & 19 & 25 & 350 & $\begin{array}{l}\text { Recovered; controlled on } \\
\text { metformin and labetalol }\end{array}$ \\
\hline 7 & $\begin{array}{c}\text { Yes } \\
\text { (on diet) }\end{array}$ & $70 / \mathrm{F}$ & Prednisolone $20 \mathrm{mg}$ & 2 wk & 45 & 144 & 5 & 18 & 24 & 361 & $\begin{array}{l}\text { Recovered; controlled on } \\
\text { phenformin }\end{array}$ \\
\hline 8 & $\begin{array}{c}\text { Yes } \\
\text { (chlorpropamide) }\end{array}$ & $75 \mathrm{~F}$ & Frusemide $80 \mathrm{mg}$ & $1 \mathrm{wk}$ & 36 & 142 & 5 & 15 & 22 & 345 & $\begin{array}{l}\text { Died of myocardial } \\
\text { infarction }\end{array}$ \\
\hline 9 & $\begin{array}{l}\text { Yes } \\
\text { (on diet) }\end{array}$ & $67 / \mathrm{F}$ & Acetazolamide $250 \mathrm{mg}$ & $10 \mathrm{~d}$ & 45 & 147 & 4 & 18 & 22 & 365 & $\begin{array}{l}\text { Recovered; controlled on } \\
\text { chlorpropamide }\end{array}$ \\
\hline 10 & $\begin{array}{c}\text { Yes } \\
\text { (on diet) }\end{array}$ & $75 / \mathrm{F}$ & Frusemide $40 \mathrm{mg}$ & $10 \mathrm{~d}$ & 43 & 153 & 5 & 21 & 27 & 380 & $\begin{array}{l}\text { Recovered; controlled on } \\
\text { insulin }\end{array}$ \\
\hline 11 & $\begin{array}{c}\text { Yes } \\
\text { (metformin) }\end{array}$ & $70 / \mathrm{F}$ & $\begin{array}{l}\text { Frusemide } 40 \mathrm{mg} ; \\
\text { oxprenolol } 80 \mathrm{mg}\end{array}$ & $6 \mathrm{mnth}$ & 37 & 170 & $5 \cdot 5$ & 31 & 23 & 419 & Died \\
\hline
\end{tabular}


are well known to diminish glucose tolerance and precipitate or aggravate diabetes and precipitate this syndrome. It was first thought that frusemide caused the syndrome only when given in large doses, ${ }^{10}$ but modest or small doses of frusemide have been implicated. ${ }^{71}$ This was seen in three of our patients who were taking frusemide $40-80 \mathrm{mg}$ daily. Bumetanide has not been reported as precipitating this syndrome, and it is claimed that bumetanide causes less disturbance of carbohydrate metabolism than other diuretics. ${ }^{12}$ Similarly, there has been no report of any case of this syndrome being precipitated by indapamide (Natrilix), a recently introduced diuretic used to treat hypertension. Beta-blockers have also been reported to precipitate the hyperosmolar non-ketotic diabetic syndrome. ${ }^{13}$ Three of our patients were taking beta-blockers when they presented with this syndrome. Two patients, however, continued taking betablockers after recovery without recurrence of the hyperosmolar state (one died). One of our patients developed the syndrome after starting treatment with prednisolone. This syndrome is known to be precipitated by glucocorticoids. ${ }^{14}$

The way in which diuretics precipitate the syndrome is still unknown. Reutter said that this side effect was due to potassium depletion. ${ }^{15}$ The hyperglycaemic effect of diuretics, however, has occurred even before potassium depletion took place, ${ }^{16}$ and equal concentrations and urinary losses of potassium have been found in patients who develop hyperglycaemia and in those who remain metabolically normal while on diuretic treatment. ${ }^{8}$ No relation has been found between the hyperglycaemic effect of diuretics and the magnitude of diuresis, nor is there any evidence that these drugs are toxic to the pancreas. ${ }^{16}$ Similarly, no evidence has been found that diuretics increase adrenocortical stimulation or decrease glucose utilisation. ${ }^{15}$ Diazoxide has been shown to inhibit insulin secretion, ${ }^{17}$ but this has not been shown with other diuretics.

Although hyperglycaemia may develop after diuretic treatment in the form of hyperosmolar non-ketotic diabetes, it is not known whether there is a direct relation between the absence of ketosis and the precipitation by diuretics. Diazoxide has been shown to increase the plasma free fatty acids without stimulating glycerol release, ${ }^{18}$ so an inhibitory effect on lipogenesis, without affecting lipolysis, has to be assumed. This syndrome occurs more commonly in elderly patients, so antihypertensive treat- ment with diuretics should be started carefully and a close watch kept on these patients over the next few months for the development of diabetes. Early intervention at the onset of symptoms may prevent the patient from reaching the late stage of hyperosmolar coma with its associated high mortality.

\section{References}

${ }^{1}$ Sament S, Schwartz MD. Severe diabetic stupor without ketosis. $S$ Afr Med f 1957;31:893-4.

2 Podolosky S. Hyperosmolar non-ketotic coma in the elderly diabetic. Med Clin N Am 1968;62:815-28.

${ }^{3}$ Brenner WI, Lansky Z, Engelman RM, et al. Hyperosmolar coma in surgical patients. Ann Surg 1973;178:651-4.

${ }^{4}$ Curtis J, Horrigan F, Ahearn D, et al. Chlorthalidone-induced hyperosmolar hyperglycaemic non-ketotic coma. FAMA 1972;220:1592-3.

5 Dollery CT, Pentecost BL, Samaan NA. Drug induced diabetes. Lancet $1962 ;$ ii: $735-7$

${ }^{6}$ Gerich JE, Martin MM, Recant L. Clinical and metabolic characteristics of hyperosmolar non-ketotic coma. Diabetes $1971 ; 20: 228-38$

${ }^{2}$ Lavender S, McGill MB. Non-ketotic hyperosmolar coma and frusemide therapy. Diabetes $1974 ; 23: 247-8$

${ }^{8}$ Shapiro AP, Benedek TG, Small JL. Effect of thiazides on carbohydrate metabolism in patients with hypertension. N Engl f Med 1961;265: 1028-31.

${ }^{9}$ Whelton MJ, Walde D, Havard CWH. Hyperosmolar non-ketotic diabetic coma with particular reference to vascular complications. $\mathrm{Br} \mathrm{Med} F$ $1971 ; \mathrm{i}: 85-6$.

10 Tasker PRW, Mitchell-Heggs PF. Non-ketotic diabetic precoma associated with high-dose frusemide therapy. $\mathrm{Br} M e d \mathcal{F} 1976 ; \mathrm{i}: 626-7$.

11 Khaleeli AA, Wyman AL. Hyperosmolar non-ketotic coma induced by frusemide in modest dosage. Postgrad Med f 1978;54:43-4.

12. Giugliano D, Varricchio $M$, Cerciello $T$, et al. Bumetanide and glucose tolerance in man. Farmaco [Prat]. $1980 ; 35: 403-8$.

13 Podolsky S. A possible role of propranolol in recurrent non-ketotic hyperosmolar diabetic coma. Diabetes 1970;19:398.

${ }^{14}$ Boyer $\mathrm{MH}$. Hyperosmolar anacidotic coma in association with glucocorticoid therapy. $\mathcal{F} A M A 1967 ; 202: 1007$.

${ }^{15}$ Reutter F, Labhart A. Saluretika und Glukosetoleranz. Helv Med Acta $1961 ; 28: 487-95$.

${ }^{16}$ Zatuchni J, Kordasz F. The diabetogenic effect of thiazide diuretics. Am $\mathcal{F}$ Cardiol $1961 ; 7: 565-7$.

17 Howell SL, Taylor KW. Effect of diazoxide on insulin secretion in vitro. Lancet $1966 ; 1: 128-9$.

18 Torsti P, Neuvonen P. Effects of diuretics on lipolysis in the rat. Ann Med Exp Biol Fenn 1967;45:403-6.

(Accepted 8 (October 1981)

\section{MATERIA NON MEDICA}

\section{"The train now arriving at platform $1 \ldots$..."}

You'll never survive the journey, they said. But I have-so far. Variety, so they also said, is the spice of life. Perhaps spicing the journey has made survival the easier, because the variety of things that can happen between Ipswich and London by train seems limitless.

Take the winter, for instance; freezing cold on the platform, welcomingly warm inside-but it's the train you want to be warm, not just the waiting room. So when it comes, late because the points were frozen down the line, it is a bit disappointing to find the locomotive has no boiler to warm up the carriages. Nothing daunted, next day you wear two overcoats; but they have changed the engine, and now it heats the train highly efficiently; though the air conditioning does not work very well, so coats off. More coats off at Colchester, and by Chelmsford it is nearly down to a strip.

It is surprising how often things find themselves on the lines which should not be there; sheep in Norfolk, bullocks in Essex, and the ticket collector in London when the train set off without him. A door was on the line one day (luckily no one seemed to have fallen out anywhere) and occasionally the wires, usually adequately slung from gantries all along the track, become detached, descend on to the lines, and cause electric havoc. Although our train is hauled by a diesel engine, the electric trains get in the way, and so it doesn't help. Just sometimes things find themselves off the lines when they should be on them. Thence the journey to London via Cambridge because a truck fell off the track on the direct route; what happened to the passengers at Manningtree I never found out. But they are used to being left behind, when the train hurtles through when it should have stopped. There again, sometimes it stops when it shouldn't-and at other stations, too, come to think of it.

Most trains are about 10 coaches long. But once we had three, which made it distinctly cosy and intimate-until the doors would not close properly. And once we had 13; that made us late because the engine could not cope. Even with 10 coaches, when the occasional toy engine puts in an appearance, that cannot cope either. If the effort is just too much and it fails completely that causes great problems, because there are no longer spare engines up and down the line. Another one has to come from Stratford, and by the time it arrives it is nearly time to go home again.

To be fair the railway company tries to be helpful; first class one end, second class the other, they say. If they said which end it would help a bit more, and if they kept to the same end that would help even more. The restaurant service is excellent, though pricy: but it is not always there, and the anticipation of finding out whether it is there or not when you want it is quite exciting.

Late at night the lights used to be dimmed for a peaceful somnolent journey home. It is bright now because the only coach for passengersletters go in the rest of the train-is so full you might stumble over bodies unless you could see them properly. It's a great journey every day, though. But it is the survival of the fittest.-FRANK WELLS, Ipswich. 